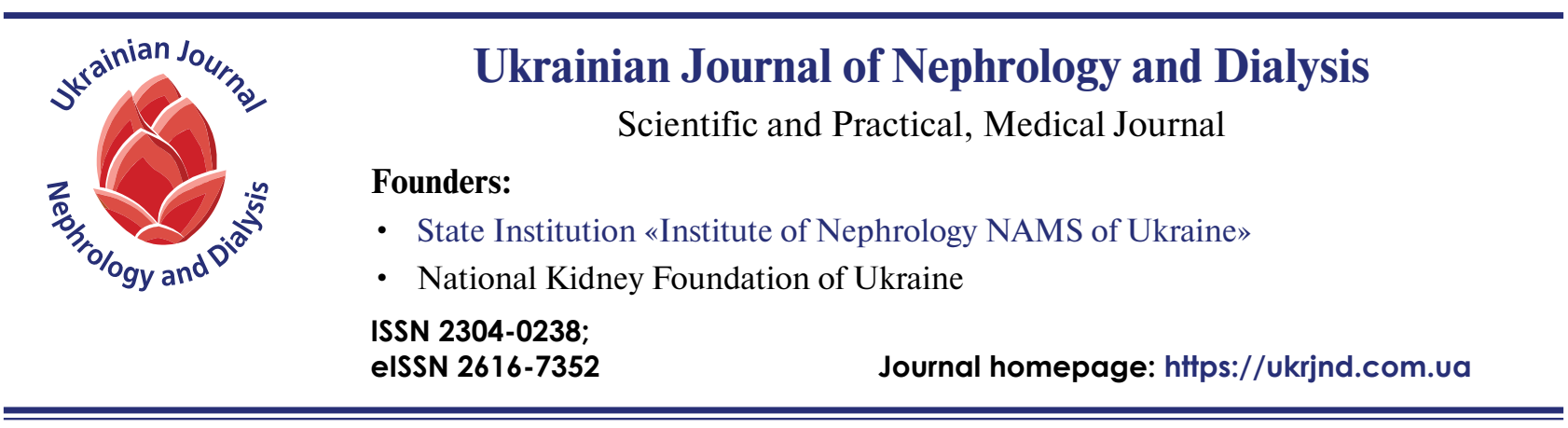

\section{Nephrology School}

doi: $10.31450 /$ ukrjnd.3(63).2019.08

\section{F. O. Prusskiy}

\section{Cardiovascular complications in hemodialysis patients: current approaches to prolong and improve quality of patients' life}

Communal non-commercial enterprise "Kyiv municipal center of nephrology and dialysis"

\section{Citation:}

\section{Article history:}

Received August 06, 2019 Received in revised form August 26, 2019 Accepted September 04, 2019
Prusskiy F. Cardiovascular complications in hemodialysis patients: current approaches to prolong and improve quality of patients' life. Ukr J Nephr Dial. 2019;3(63):53-61. doi: 10.31450/ukrJnd.3(63).2019.08

Summary. Cardiovascular complications are a leading cause of morbidity and mortality in dialysis patients. Cardiovascular mortality is more than $40 \%$ of the total mortality in this cohort of patients. Recently, there has been an increase in publications on the role of uremic toxins, including "middle molecules", in the development and progression of cardiovascular complications in dialysis patients.

Conventional low-flux (LF) hemodialysis well removes small molecular weight uremic toxins not bound with protein. Evidence for the role of "middle molecules" in the development of many complications, including cardiovascular complications, has contributed to the emergence and development of such dialysis therapy methods as high-flux (HF) hemodialysis, hemofiltration (HF) and hemodiafiltration (HDF).

Further evolution of membrane technology has led to the development of proteinleaking membranes or super-flux or high cutoff (HCO) membranes. These membranes are capable of removing molecules in excess of the molecular weight of albumin. The use of these membranes is limited because of the risk of hypoalbuminemia.

Today, the closest approximation to the natural glomerular membrane is the so-called Middle Cut-Off (MCO) membrane. The use of MSO membranes is implemented in a new method of dialysis therapy - expanded hemodialysis (HDx). The method is defined as a treatment where diffusion and convection are conveniently combined inside a hollow-fibre dialyser equipped with an MCO membrane. A standard hemodialysis machine is used for the HDx. Increased removal of large medium molecules in HDx may lead to an improvement of clinical outcomes, including a decrease of the cardiovascular events incidence, an all-cause and cardiovascular mortality reduction in dialysis patients.

Keywords: cardiovascular complications, uraemic toxins, dialysis membranes, expanded haemodialysis.

Conflict of interest statement: this work was supported by an academic support grant provided by the Baxter.

(C) M. Malasaiev, I. Dudar, A. Shymova, 2019. All rights reserved. Correspondence should be addressed to Fedir Prusskiy: fedor7777@ukr.net 


\section{Ф. О. Прусський}

\section{Серцево-судинні ускладнення у хворих, які лікуються гемодіалізом: сучасні підходи для пролонгації та підвищення якості життя пацієнтів}

Комунальне некомерційне підприємство “Київський міський центр нефрології та діалізу”

Резюме. Серцево-судинні ускладнення є провідною причиною смертності діалізних хворих, на яку припадає понад 40\% загальної смертності. Останнім часом з'являється все більще публікацій присвячених ролі накопичення уремічних токсинів, зокрема середніх молекул, у розвитку та прогресуванні серцево-судинних ускладнень у діалізних хворих.

Звичайний «низькопоточниий» (LF-low flux) гемодіаліз добре видаляє низькомолекулярні уремічні токсини, не зв'язані з білками. Поява доказів ролі «середніх молекул» у розвитку багатьох ускладнень, зокрема серцево-судинних, сприяло появі та розвитку таких методів діалізної терапії як високопоточний (HF - high flux) ГД, гемофільтрація (ГФ) та гемодіафільтрація (ГДФ).

Подальша еволюція мембранної технології призвела до розробки білок-проникних мембран, які також називаються мембранами з надмірним потоком або мембранами з високою точкою відсікання (HCO, High cut-off). Ці мембрани здатні видаляти молекули з масою, що перевищує молекулярну масу альбуміну. Застосування таких мембран обмежене через небезпеку гіпоальбумінемії.

На сьогоднішній день максимальним наближенням до природної гломерулярної мембрани можна вважати так звані мембрани з середньюю точкою відсікання (Middle cut-off, MCO). Використання МСО мембран реалізовано в новому методі діалізної терапї - розширеному гемодіалізі (HDx). Метод визначено як гемодіаліз, який поєднує дифузний і конвекційний транспорт в оптимальному співвідношенні за рахунок використання діалізаторів із середньою точкою відсікання. Для проведення розширеного ГД використовується стандартний гемодіалізний апарат. Підвищене видалення великих середніх молекул при HDx може призвести до покращення клінічних наслідків, зокрема зменшення частоти розвитку серцево-судинних ускладнень, зниження загальної та серцево-судинної смертності у діалізних пацієнтів.

Ключові слова: серцево-судинні ускладнення, уремічні токсини, гемодіаліз, діалізні мембрани, розиирений гемодіаліз

Незважаючи на досягнення в сфері діалізних технологій, пацієнти, які лікуються гемодіалізом, все ще мають високі показники госпіталізації, низьку якість життя та високу смертність. Смертність від усіх причин даної когорти хворих залишається стабільно високою - > 20\% щорічно та в 10 разів перевищує цей показник в загальній популяції [1]. 5-річна виживаність становить лише близько 40\% незалежно від режиму діалізу, та є гіршою, ніж у багатьох видів раку [1-3]. Серцево-судинні ускладнення $є$ провідною причиною захворюваності та смертності у діалізних хворих. Серцевосудинна смертність становить більш ніж 40\% загальної смертності в цій групі, а більшість смертей трапляються через серцеву недостатність, гострий інфаркт міокарда і смертельну аритмію [1, 4-8].

В Україні загальна смертність серед хворих які отримують лікування методом ГД та гемодіафільтрації (ГДФ) в 2017 р. становила 10,5 та 7,1\% відповідно, при цьому серцево-судинні захворювання

Прусський Федір Олександрович fedor7777@ukr.net переважали в структурі смертності - смертність від серцево-судинних захворювань склала 71,1 та 73,2\% від загальної смертності [9].

Характеристики серцево-судинної дисфункції, що спостерігаються у хворих на діалізі, відрізняються від тих, що відзначаються в загальній популяції. Поряд з традиційними серцево-судинними факторами ризику у діалізних пацієнтів дуже поширені й нетрадиційні (Табл. 1) [10], вони відіграють велику роль у надмірній серцево-судинної захворюваності та смертності у хворих, які лікуються діалізними методами [10-12].

Таблиця 1

\section{Серцево-судинні фактори ризику} у діалізних хворих

\begin{tabular}{|l|l|}
\hline \multicolumn{1}{|c|}{ Традиційні ФP } & \multicolumn{1}{|c|}{ Нетрадиційні ФР } \\
\hline Цукровий діабет & Анемія \\
Артеріальна гіпертензія & Хронічне запалення \\
Дисліпідемія & Гіперфосфатемія \\
Ожиріння & Інсулінорезистентність \\
Сидячий спосіб життя & Оксидативний стрес \\
Паління & Кальцифікація \\
Похилий вік & коронарних судин \\
& Ендотеліальна \\
& дисфункція \\
& Уремічні токсини \\
\hline
\end{tabular}


Патофізіологічні механізми розвитку серцевосудинних ускладнень у діалізних пацієнтів є складними і не повністю зрозумілими. Деякі фактори, пов'язані з термінальною хронічною нирковою недостатність, зокрема активація системи ренін-ангіотензин-альдостерон (РААС), симпатичної нервової системи (СНС), накопичення кінцевих продуктів глікозування (AGE, advanced glycation end product), порушення фосфор-кальцієвого метабо- лізму, оксидативний стрес, а також накопичення уремічних токсинів, сприяють розвитку серцевосудинної патології. До таких змін відносяться кардіоміопатія (уремічна кардіоміопатія), гіпертрофія лівого шлуночка (ЛЖ), фіброз міокарда, порушення діастолічного наповнення та ураження дрібних коронарних судин. Судинні зміни, що включають атеросклероз, кальцифікацію судин і втрату еластичності судин, показані на рис. $1[11,12]$.

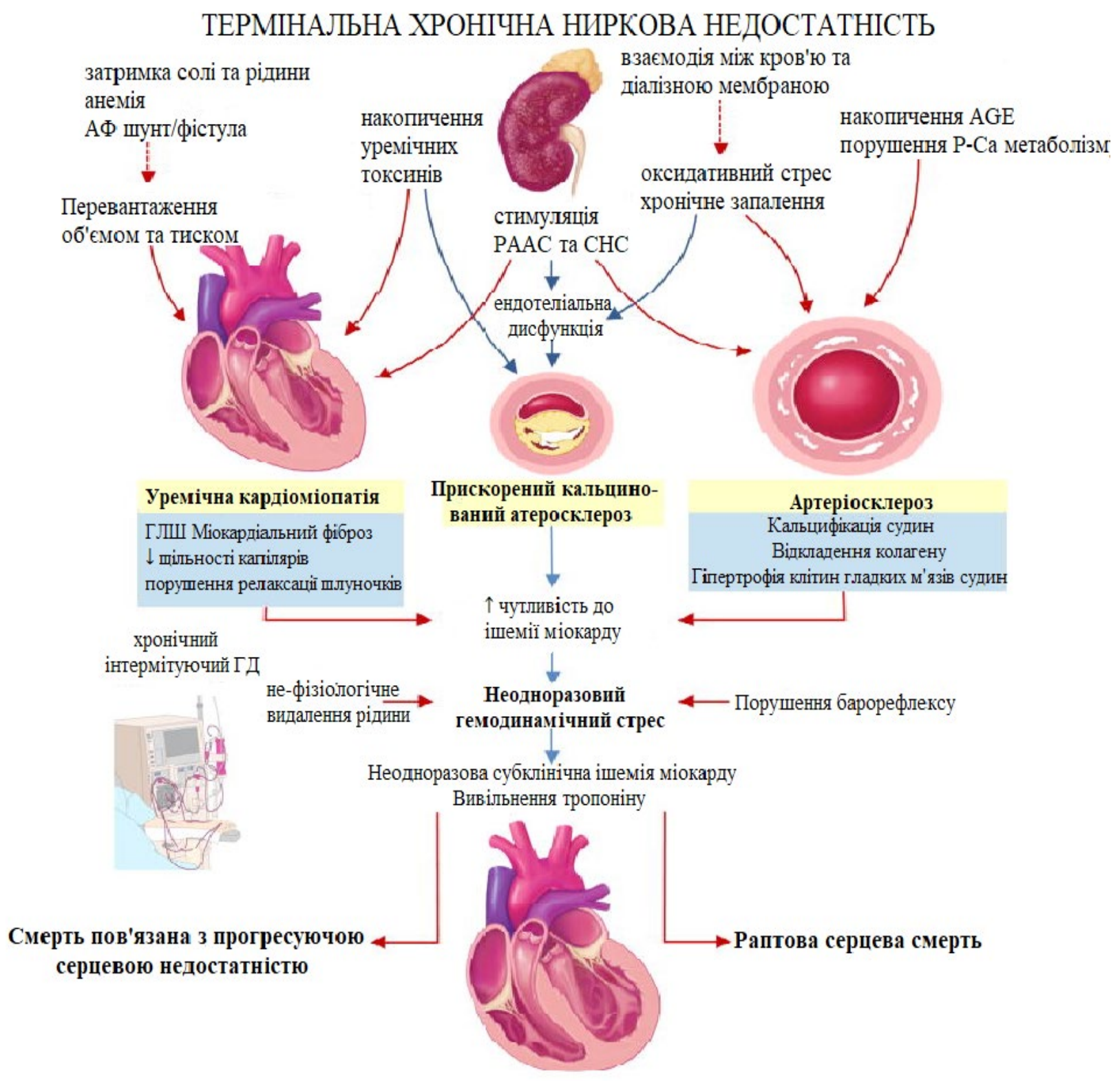

Рис. 1. Патофізіологічні механізми індукованого гемодіалізом ушкодження міокарда

Останнім часом з'являється все більше публікацій присвячених ролі накопичення уремічних токсинів, зокрема середніх молекул, у розвитку та прогресуванні серцево-судинних ускладнень у діалізних хворих [13-15].

Уремічні токсини, унікальні для пацієнтів 3 хронічною хворобою нирок (ХХН), належать до групи нетрадиційних факторів ризику серцевосудинних захворювань (СС3).

Залучення різних уремічних токсинів до чотирьох основних доменів СС3 (атеросклероз, ураження міокарда, ураження клапанів, аритміі) узагальнено в таблиці 2 [14]. 
Таблиия 2

Вплив уремічних токсинів на розвиток основних СС3

\begin{tabular}{|l|c|c|c|c|}
\hline \multirow{2}{*}{\multicolumn{2}{|c|}{ Уремічний токсин }} & \multicolumn{3}{c|}{ Серцево-судині ускладнення } \\
\cline { 2 - 5 } & $\begin{array}{c}\text { Атеро- } \\
\text { склероз }\end{array}$ & $\begin{array}{c}\text { Ураження } \\
\text { міокарду }\end{array}$ & $\begin{array}{c}\text { Ураження } \\
\text { клапанів }\end{array}$ & Аритмії \\
\hline Кінцеві продукти глікозування & + & & & \\
\hline Ангіогенін-DIР I & + & & & \\
\hline 2-мікроглобулін & + & + & & \\
\hline Фактор D комплементу & + & & & \\
\hline Цитокіни & + & + & $?$ & $?$ \\
\hline Дінуклеотид поліфосфат & + & & & \\
\hline Гомоцистеїн & + & & & \\
\hline Індоксил сульфат & + & & & \\
\hline Лептин & + & & & \\
\hline Паратиреоїдний гормон & & & + & \\
\hline Фосфати & & & + & \\
\hline
\end{tabular}

Основна частина представлених вище токсинів відноситься до так званих середніх молекул, тобто речовин з молекулярною масою $\geq 500$ Да [16-17].

Ефективне видалення широкого спектру уремічних токсинів $є$ основним завданням всіх діалізних методів лікування.

Звичайний «низькопоточниий» (LF - low flux) гемодіаліз добре видаляє низькомолекулярні уремічні токсини, не зв язані з білками. Однак ще на початку становлення гемодіалізу як методу лікування ХХН визначалося, що виведення низькомолекулярних уремічний токсинів не вирішує всіх клінічних проблем, а пацієнти на перитонеальному діалізі з більш високими рутинними показниками азотемії демонструють не гіршу, а для полінейропатії - кращу корекцію уремічних синдромів. Останнє спостереження було пояснено більш ви- сокою проникністю перитонеальної мембрани, ніж у низкопоточной целюлозних мембран, що використовувалися в той час. Ці та інші спостереження стали основою гіпотези «середніх молекул» та сприяли розробці і виробництву більш високопоточних діалізних мембран [18]. У спробі поліпшити клінічні наслідки діалізних пацієнтів були розроблені альтернативні методи ниркової замісної терапії, тому шо видалення шляхом дифузії стає менш ефективним із зростанням молекулярної маси розчиненої речовини. Таким чином, для видалення «середніх молекул» необхідно наближення діалізних мембран за властивостями до ниркового фільтру, оскільки дифузія в канальцях і петлі Генле слідує за фільтрацією в клубочці, що є принципом конвекції (рис. 2) [19].

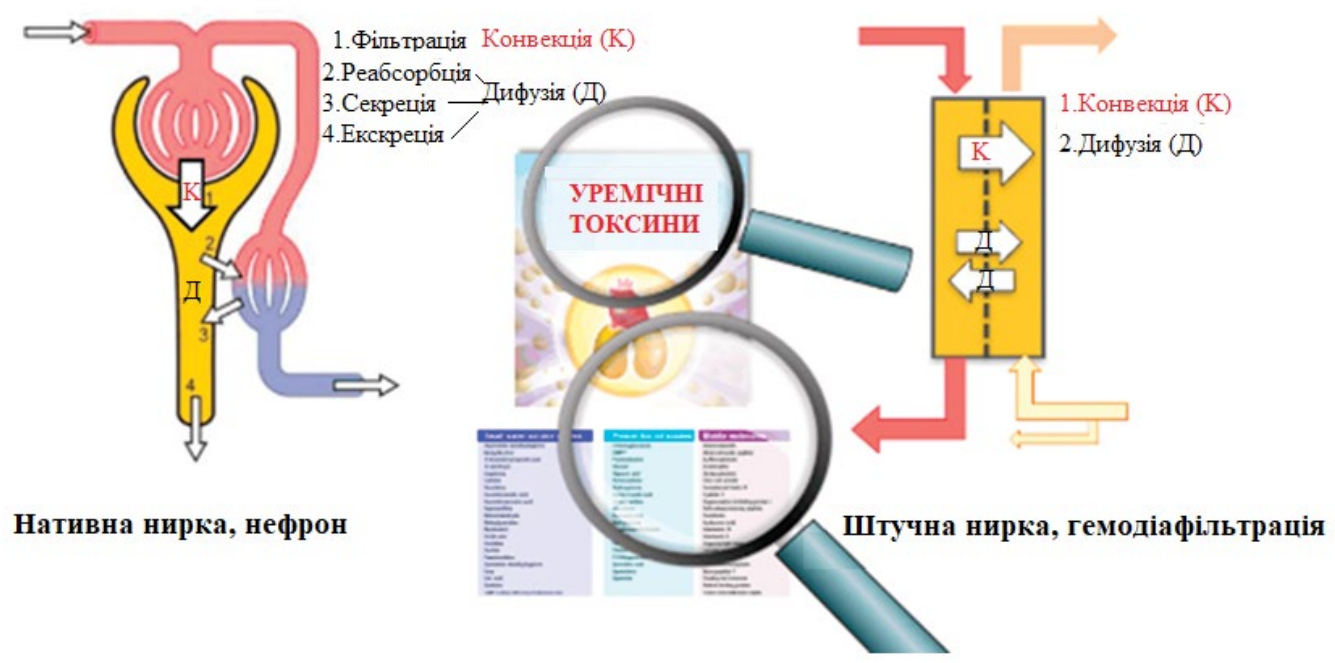

Рис. 2. Імітація функції нативної нирки для поліпшення видалення «середньої молекули». 
Таким чином, все це сприяло появі та розвитку таких методів діалізної терапії як високопоточний (HF - high flux) ГД, гемофільтрація (ГФ) та гемо- діафільтрація (ГДФ). Співвідношення між діалізними методами, процесами і молекулярною вагою розчинених речовин показані на рис. 3 [19].

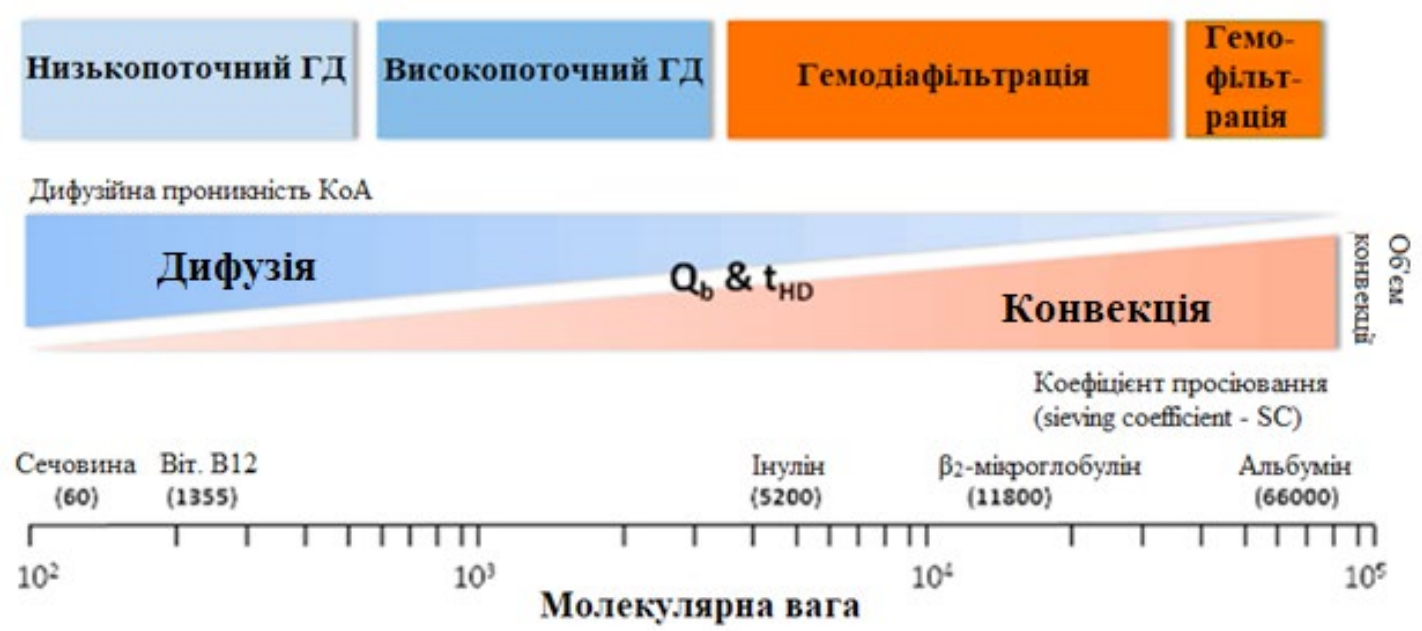

Рис. 3. Співвідношення між діалізними методами, процесами і молекулярною вагою розчинених речовин. КоА, коефіцієнт масопереносу сечовини; QB, кровотік; tHD, тривалість сеансу ГД; SC, коефіцієнт просіювання (частка речовини, що підлягає видаленню для конкретного фільтра).

Поява апаратів з системами ультрафільтрації (УФ) 25 років тому призвело до широкого застосування високопоточних мембран. Завдяки їхній високій гідравлічній проникності і більшим розмірам пор, такі мембрани збільшили виведення «середньої молекули» і дозволили розробити нові технології, такі як гемофільтрація і ГДФ [20, 21].

Вихідні спостереження з обсерваційних досліджень про переваги високопоточних мембран передбачалося підтвердити в двох великих рандомізованих клінічних дослідженнях (РКД): Hemodialysis (HEMO) Study [2] i Membrane Permeability Outcome (MPO) Study [22]. Але в жодному з них за умови первинного аналізу не було отримано свідчень переваги високопоточних мембран, хоча в окремих підгрупах в post hoc аналізі переваги все ж були продемонстровані.

Що стосується ГДФ, то в серії з чотирьох великих РКД тільки в одному переваги було підтверджено в первинному аналізі [23]. При цьому в об'єднаному аналізі цих РКД перевага в зниженні смертності (загальної та серцево-судинної) при ГДФ в режимі пост-дилюції було отримано тільки при конвекційному об'ємі вище 23 літрів [24].

У той же час, досягнення таких конвекційних об’ємів в режимі пост-дилюції не завжди можливо або пов'язано з ризиками тромбування і погіршення дифузійних властивостей діафільтру при неможливості досягти досить високої швидкості кровотоку.

Обмежені свідоцтва переваг ГДФ, невпевненість в можливості досягти цільових значень за конвекційним об'ємом разом 3 додатковими ви- тратами на проведення ГДФ стимулювали пошук можливостей інтенсифікації видалення середньомолекулярних речовин конвекційною технологією в рамках сеансу гемодіалізу.

Подальша еволюція мембранної технології призвела до розробки білок-проникних мембран, які також називаються мембранами 3 надмірним потоком або мембранами з високою точкою відсікання (HCO, High cut-off) [25]. Ці мембрани здатні видаляти молекули з масою, що перевищує молекулярну масу альбуміну, а для $\beta 2$-мікроглобуліну мають коефіцієнт просіювання близько 100\%. Застосування таких мембран обмежена, вони можуть використовуватись при гострому пошкодженні нирок при мієломної хвороби, сепсисі, рабдоміолізі. У хворих на програмному гемодіалізі у зв'язку з небезпекою гіпоальбумінемії вони використовувалися лише в рамках короткострокових досліджень [26].

Сучасні технології дозволяють виробляти мембрани з чітко заданими властивостями. В ідеальному варіанті, оснастивши мембрану порами, розподіл яких по величині буде перебувати в вузьких межах, можна домогтися істотного збільшення спектру виведених в ході лікування речовин і уникнути при цьому втрати значних кількостей альбуміну. Така мембрана буде максимально повно моделювати властивості з просіювання природної гломерулярної мембрани. На сьогоднішній день максимальним наближенням до подібної ідеальної мембрані можна вважати так звані мембрани з середньою точкою відсікання (Middle cut-off, MCO) [27]. Просіювальні властивості мембран прийнято 
характеризувати двома параметрами: точкою початку відсікання (або retention onset $(\mathrm{RO})$ - «поріг затримки»), тобто молекулярною масою речовин, коефіцієнт просіювання для яких становить 90\%, i точкою закінчення відсікання (cut off (CO) - «точка відсікання»), що представляє молекулярну масу речовин з коефіцієнтом просіювання 10\% [27]. На відміну від НСО-мембран, у яких проміжок між цими точками досить великий, що визначається більш широкої дистрибуцією пор мембрани за розміром, МСО-мембрани характеризуються досить компактним проміжком між точками початку і закінчення відсікання (рис. 4), і відповідно, більш регулярним розміром пор.

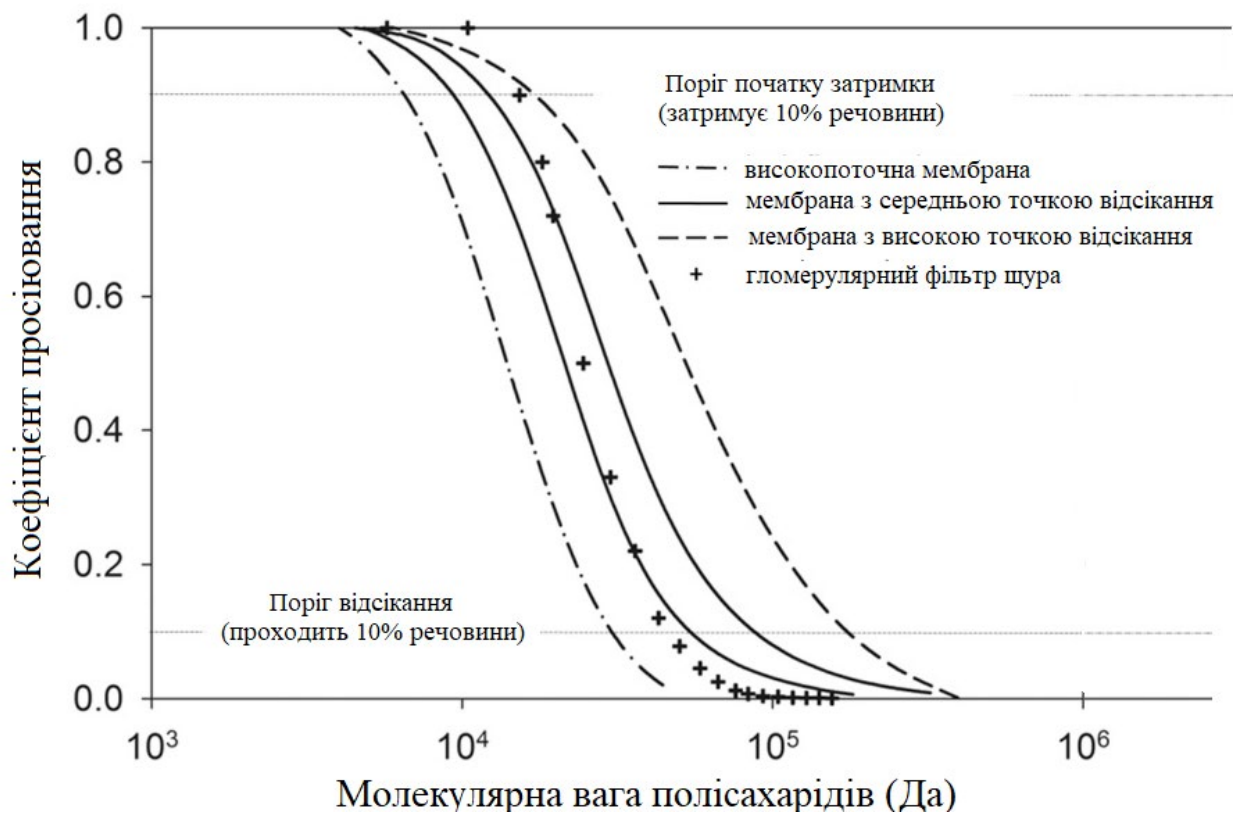

Рис. 4. Характеристики мембрани з середньою точкою відсікання в порівнянні зі стандартними високопоточними мембранами, мембранами з високою точкою відсікання і нирковим фільтром [28].

Перші клінічні дослідження МСО-мембран підтверджують їх здатність більшою мірою знижувати концентрації прозапальних цитокінів, таких як фактор некрозу пухлин і інтерлейкін 6, вільних легких ланцюгів імуноглобулінів каппа і лямбда, 1-мікроглобуліну, фактор комплементу D [29, 30] порівняно з класичними високопоточними мембранами. Тенденція до гіпоальбумінемії, що спо- стерігалася протягом першого місяця лікування на MCO-мембранах, нівелювалася в ході подальших 8 тижнів, що автори пов'язують з позитивним впливом мембран з підвищеною проникністю на стан хронічного запалення, характерного для пацієнтів з нирковою дисфункцією [31].

Сучасна класифікація діалізних мембран (щодо проникності) представлена у таблиці 2 [28].

Таблиия 2

Класифікація діалізних мембран

\begin{tabular}{|c|c|c|c|c|c|}
\hline \multirow[b]{2}{*}{ Категорія } & \multirow{2}{*}{$\begin{array}{c}\text { Коефіцієнт } \\
\text { ультрафіль-трації1 } \\
\text { (мл/год/ммНg/м²) }\end{array}$} & \multicolumn{2}{|c|}{ 2-мікроглобулін } & \multicolumn{2}{|c|}{ Альбумін } \\
\hline & & $\begin{array}{l}\text { Кліренс }{ }^{2} \\
\text { (мл/хв) }\end{array}$ & $\begin{array}{c}\text { коефіцієнт } \\
\text { просіювання }^{1}\end{array}$ & $\begin{array}{c}\text { Втрата } 3 \\
\text { діалізатом }^{3} \\
\text { (г) } \\
\end{array}$ & $\begin{array}{c}\text { коефіцієнт } \\
\text { просіювання }\end{array}$ \\
\hline LF & $<12$ & $<10$ & - & 0 & 0 \\
\hline $\mathrm{HF}$ & $14-40$ & $20-80$ & $<0,7-0,8$ & $<0,5$ & $<0,01$ \\
\hline $\mathrm{MCO}$ & $40-60$ & $>80$ & 0,99 & $2-4$ & $<0,01$ \\
\hline $\begin{array}{l}\text { Білок- } \\
\text { проникні }\end{array}$ & $>40$ & $>80$ & $0,9-1,0$ & $2-6$ & $0,01-0,03$ \\
\hline $\mathrm{HCO}$ & $40-60$ & - & 1,0 & $9-23$ & $<0,2$ \\
\hline
\end{tabular}

Примітка. $\quad{ }^{1}$ In vitro. ${ }^{2}$ Для конвекційного ГД з швидкістю кровотоку 300-400 мл/хв. ${ }^{3}$ Для 4 год конвекційного ГД. MCO - Medium cut-off, середня точка відсікання, HCO - High cut-off, висока точка відсікання. 
Слід зазначити, що говорити про дифузійний трансмембранний перенос при проведенні гемодіалізу на високопроникних мембранах варто лише щодо низькомолекулярних сполук, молекули яких внаслідок невеликих розмірів і надзвичайної рухливості в розчині легко проникають крізь пори мембрани з контуру крові в діалізуючий розчин. Великі молекули, такі як $\beta 2$-мікроглобулін, відрізняються інертністю і невисокою здатністю самостійно долати бар'єр мембрани. Їх виведення при гемодіалізі відбувається переважно за рахунок так званої «внутрішньої» фільтрації - феномена, що виникає за умови проведення високопоточного діалізу, і пов язано з швидким падінням тиску в високопроникному полому волокні, що призводить до зворотної фільтрації з діалізату в контур крові на виході з діалізатору. Внутрішні конвективні потоки кількісно можуть бути вельми значущими [31] і в значному ступені визначати кліренс високомолекулярних речовин. Тому гемодіаліз на МСО-мембранах внаслідок більш активної внутрішньої фільтрації може бути порівнянний 3 високооб'ємною онлайн-ГДФ щодо виведення $\beta 2-$ мікроглобуліну за рахунок більш високого коефіцієнта просіювання (90\% vs 60\%) [27].

Такий підхід ліг в основу пропозиції додати в номенклатуру діалізних методів поняття розширеного (expanded) діалізу - HDx [15, 27]. Метод визначено як гемодіаліз, який поєднує дифузний i конвекційний транспорт в оптимальному співвідношенні за рахунок використання діалізаторів із середньою точкою відсікання. Для проведення розширеного ГД використовується стандартний гемодіалізний апарат.

По суті, технологія розширеного діалізу частково відтворює мід-ділюційну ГДФ (введення заміщуючого розчину в кровоток в середині діалізаторів спеціальної конструкції - малодоступні специфічні апарат і витратні матеріали), але на стандартному гемодіалізному апараті: на першому відрізку діалізаторів відбувається фільтрація, а на другому - заміщення (зворотна фільтрація). При цьому надлишкової гемоконцентрації ніде не створюється, а дифузний кліренс не страждає.
Акцент зроблений на тому, що конвекційний транспорт, необхідний для видалення середніх i великих уремічний токсинів, прихований всередині діалізаторів з середньою точкою відсікання. Основи цих ідей закладені ще десятиліття тому [32]. Зменшення внутрішнього діаметра капілярів (виконане для зміни співвідношення осьового і радіального опору на користь конвекційного потоку) одночасно збільшує швидкість потоку крові і напруження зсуву на внутрішній поверхні капіляра, що надає очищуючий ефект на поверхню мембрани і покращує дифузний транспорт розчинених речовин [33]. Комбінація гідравлічної проникності і геометричної структури волокон посилює внутрішню фільтрацію і зворотну фільтрацію.

Важливо відзначити, що кровоток в 300 мл/хв достатній для ефективної роботи цього механізму. Це справедливо й для потоку діалізуючого розчину в 500 мл/хв. У зв'язку зі значними об'ємами зворотної фільтрації оптимальним є використання води з такою ж мірою очищення, як і для ГДФ, хоча обов'язковим це не вважається.

Розширений гемодіаліз використовує нове покоління мембран гемодіалізу, які вперше дозволяють ефективно видаляти великі середні молекули без значної втрати альбуміну. Описані патогенетичні механізми впливу цих молекул на розвиток та прогресування серцево-судинних захворювань, вторинного імунодефіциту, хронічного запалення тощо. Потенційно підвищене видалення великих середніх молекул може призвести до покращення клінічних наслідків, зокрема зменшення частоти розвитку серцево-судинних ускладнень, зниження загальної та серцево-судинної смертності у діалізних пацієнтів. Однак ця гіпотеза повинна бути підтверджена в надійних клінічних дослідженнях.

Конфлікт інтересів: робота була підтримана науковим грантом, наданим компанією Baxter.

\section{Інформація про внесок кожного учасника.}

Ф. Прусський: збір та аналіз літературних джерел, підготовка статті до друку.

\section{References (Література):}

1. US Renal Data System 2018 Annual Data Report. Volume 2 - ESRD in the United States Chapter 5: Mortality. Am J Kidney Dis. 2019;73(3S1):411426. doi: 10.1053/j.ajkd.2018.12.016.

2. Eknoyan G, Beck GJ, Cheung AK, Daugirdas JT, Greene $T$ et al. Effect of dialysis dose and membrane flux in maintenance hemodialysis. N Engl J Med. 2002; 347(25):2010-9. doi: 10.1056/ NEJMoa021583.
3. Naylor KL, Kim SJ, McArthur E, Garg AX, McCallum $M K$, Knoll GA. Mortality in Incident Maintenance Dialysis Patients Versus Incident Solid Organ Cancer Patients: A Population-Based Cohort. Am J Kidney Dis. 2019;73(6):765-776. doi: 10.1053/j.ajkd.2018.12.011.

4. US Renal Data System 2018 Annual Data Report. Volume 2 - ESRD in the United States Chapter 8: Cardiovascular Disease in Patients with ESRD. Am J Kidney Dis. 2019;73(3S1):463-500. doi: 10.1053/j.ajkd.2018.12.020. 
5. de Jager DJ, Grootendorst DC, Jager KJ, van Dijk PC, Tomas LM, Ansell D, et al. Cardiovascular and noncardiovascular mortality among patients starting dialysis. JAMA. 2009;302:1782-9. doi: 10.1001/jama.2009.1488.

6. Mavrakanas TA, Charytan DM. Cardiovascular complications in chronic dialysis patients. Curr Opin Nephrol Hypertens. 2016;25(6):536-544. doi: 10.1097/MNH.0000000000000280.

7. Carrero JJ, de Jager DJ, Verduijn $M$, Ravani $P$, De Meester $J$ et al. Cardiovascular and Noncardiovascular Mortality among Men and Women Starting Dialysis. CJASN 2011;6(7):172230. doi: https://doi.org/10.2215/CJN.11331210.

8. Foley $R N$ Clinical epidemiology of cardiovascular disease in chronic kidney disease. J Ren Care. 2010;36(1):4-8. doi: 10.1111/j.17556686.2010.00171.x.

9. Natsionalnyi reiestr khvorykh na khronichnu khvorobu nyrok ta patsiientiv z hostrym poshkodzhenniam nyrok: 2017 rik / uklad. N.I. Kozliuk, S.S. Nikolaienko, O.O. Razvazhaieva; Derzhavna ustanova „Instytut nefrolohii NAMN Ukrainy”; hol. red. M. O. Kolesnyk. - K., 2018. - 183p. [in Ukrainian].

10. Coimbra $S$, do Sameiro Faria $M$, Miranda $V$, Belo L, Santos-Silva A Cardiovascular Risk Factors in End-Stage Renal Disease Patients: The Impact of Conventional Dialysis versus OnlineHemodiafiltration / Aspects in Dialysis. Edited by Ayman Karkar. Published: December 20th 2017, IntechOpen. doi: 10.5772/intechopen.70465.

11. Chirakarnjanakorn $S$, Navaneethan $S D$, Francis $G S$, Tang $W H$. Cardiovascular impact in patients undergoing maintenance hemodialysis: Clinical management considerations. Int J Cardiol. 2017;232:1223. doi:10.1016/j.ijcard.2017.01.015.

12. Cozzolino M, Mangano $M$, Stucchi A, Ciceri $P$, Conte F, Galassi A. Cardiovascular disease in dialysis patients. Nephrol Dial Transplant. 2018;33(suppl_3):iii28-iii34. doi:10.1093/ndt/ gfy 174.

13. Wolley MJ, Hutchison CA. Large uremic toxins: an unsolved problem in end-stage kidney disease. Nephrol Dial Transplant. 2018;33(suppl_3):iii6iii11. doi:10.1093/ndt/gfy179.

14. Moradi H, Sica DA, Kalantar-Zadeh $K$. Cardiovascular Burden Associated with Uremic Toxins in Patients with Chronic Kidney Disease. Am J Nephrol 2013;38:136-148. doi: 10.1159/000351758.

15. Ronco C, La Manna G. Expanded Hemodialysis: A New Therapy for a New Class of Membranes. Contrib Nephrol. 2017;190:124-133. doi: 10.1159/000468959.
16. Vanholder $R$, Van Laecke $S$, Glorieux $G$ : What is new in uremic toxicity? Pediatr Nephrol 2008;23:12111221. doi: 10.1007/s00467-008-0762-9.

17. Vanholder R, De Smet R, Glorieux G et al. Review on uremic toxins: classification, concentration, and interindividual variability. Kidney Int. 2003;63:19341943. doi: 10.1046/j.1523-1755.2003.00924.X.

18. Babb AL, Ahmad S, Bergstrm J, Scribner BH. The middle molecule hypothesis in perspective. Am $\mathbf{J}$ Kidney Dis. 1981 Jul;1(1):46-50.

19. Imamovi G, Canaud B, Mehmedovi N, Scholz, C. Principles of Haemodiafiltration: Rationale for Improved Patients' Survival. / Advances in Hemodiafiltration Edited by Ayman Karkar. Published: September 7th 2016, IntechOpen. doi: 10.5772/63067.

20. Ronco C. Hemodiafiltration: evolution of a technique towards better dialysis care. Contrib Nephrol 2011;168:19-27. doi: 10.1159/000321741.

21. Ronco C, Crepaldi C, Brendolan A. et al. Evolution of synthetic membranes for blood purification: the case of the Polyflux family. Nephrol Dial Transplant 2003; 18(Suppl 7):10-20. doi: 10.1093/ ndt/gfg1073.

22. Locatelli F, Martin-Malo A, Hannedouche $T$, et al. Effect of membrane permeability on survival of hemodialysis patients. $\mathrm{J}$ Am Soc Nephrol. 2009;20(3):645-654. doi:10.1681/ ASN.2008060590.

23. Zemchenkov AYu, Gerasimchuk RP, Sabodash $A B$ Gemodiafiltratsiya: vnimanie na ob'em (obzor literaturyi). Nefrologiya i dializ. 2014;16(1):128-138. [In Russian].

24. Peters SA, Bots ML, Canaud B, Davenport A, Grooteman MP et al. Haemodia ltration and mortality in end-stage kidney disease patients: a pooled individual participant data analysis from four randomized controlled trials. Nephrol Dial Transplant. 2016;31(6):978-84. doi: 10.1093/ndt/gfv349.

25. Ward RA. Protein-leaking membranes for hemodialysis: a new class of membranes in search of an application? J Am Soc Nephrol. 2005;16:2421-2430. doi: 10.1681/ASN.2005010070.

26. BoschettideFierro A, Voigt $M$, Storr $M$, Krause $B$. Extended characterization of a new class of membranes for blood purifcation: the high cut-off membranes. Int J Artif Organs. 2013;36: 455-463. doi: $10.5301 /$ ijao. 5000220

27. Ronco $C$. The rise of expanded hemodialysis. Blood Purif. 2017; 44(2): I-VIII. doi: 10.1159/000476012.

28. Storr $M$, Ward RA. Membrane innovation: closer to native kidneys. Nephrol Dial Transplant. 2018;33(suppl_3):iii22-iii27. doi:10.1093/ndt/gfy228. 
29. Kirsch AH, Lyko R, Nilsson LG, Beck W, Amdahl M, Lechner $P$ et al. Performance of hemodialysis with novel medium cut-off dialyzers. Nephrol Dial Transplant. 2017; 32 (1): 165-172. doi: 10.1093/ ndt/gfw310.

30. Zickler D, Schindler R, Willy K, Martus P, Pawlak M, Storr $M$ et al. Medium Cut-Off (MCO) Membranes Reduce Inflammation in Chronic Dialysis Patients - A Randomized Controlled Clinical Trial. PLoS One. 2017;12(1):e0169024. doi: 10.1371/journal. pone. 0169024 .

31. Fiore GB, Guadagni G, Lupi A, Ricci Z, Ronco $C$. A new semiempirical mathematical model for pre- diction of internal filtration in hollow fiber hemodialyzers. Blood Purif. 2006; 24: 555-568 doi: 10.1159/000097079.

32. Ronco $C$. Fluid mechanics and cross ltration in hollow-fiber hemodialyzers. Contrib Nephrol. 2007;158:34-49. doi: 10.1159/000107233.

33. Ronco $C$, Marchionna $N$, Brendolan $A$ et al. Expanded haemodialysis: from operational mechanism to clinical results. Nephrol Dial Transplant. 2018;33(suppl_3):41-47. doi: 10.1093/ndt/gfy202. 